\title{
PERBANDINGAN KUALITAS MATERIAL BEARING MERK SKF, FMB, NKK, DAN JAL TERHADAP TERHADAP SIFAT FISIS DAN MEKANIS
}

\author{
Masryukan, Ngafwan, dan Taufik Surya Nugroho \\ Teknik Mesin Universitas Muhammadiyah Surakarta \\ Jl. A. Yani Tromol Pos I Pabelan, Kartosura \\ Email:masyrukan@ums.ac.id
}

\begin{abstract}
ABSTRAK
Penelitian ini bertujuan untuk mengetahui kualitas bahan yang digunakan pada empat merk bearing ( $S K F, F M B, N K K$, dan JAL) berdasarkan data-data pengujian sifatsifat mekanik serta struktur intern (struktur mikro) pada benda uji tersebut dan dapat membandingkan ketahanan dan kekuatan keempat merk bearing tersebut berdasarkan analisis pengujian terhadap kegunaannya. Pengujian yang dilakukan meliputi pengujian kekerasan menggunakan alat Micro Vickers Hardness Tester, pengamatan struktur mikro menggunakan alat Olympus Metallurgical Microscope dan Olympus Phtomicrographics Systems, serta pengujian kekasaran permukaan menggunakan alat Surfcorder. Pengujian kekerasan maupun struktur mikro dilakukan pada bagian cincin luar bantalan (outer bearing) dan ball bearing. Sedangkan pengujian kekasaran permukaan hanya pada bagian outer bearing. Setelah dilakukan semua pengujian dapat disimpulkan bahwa berdasarkan kekuatan, kekerasan (ketahanan aus) serta kekasaran permukaan pada bagian outer bearing dan ball bearing maka merk yang memenuhi kualitas optimum adalah merk FMB karena sudah mencukupi dengan parameter kerja bantalan sehingga membuat umur pakai lebih panjang pada aspek penggunaan yang sama.
\end{abstract}

Kata kunci: bearing, kekerasan, struktur mikro, kekasaran permukaan

\begin{abstract}
This study aims to determine the quality of materials used in four bearing brands (SKF, FMB, NKK, and JAL) based on data testing of mechanical properties as well as internal structure (micro structure) on the specimens and can compare the endurance and the strength of the four brands bearings based on the test analysis of its usefulness. The tests include hardness testing using the Micro Vickers Hardness Tester tool, microstructure observation using Olympus Metallurgical Microscope and Olympus Phtomicrographics Systems, and surface roughness testing using Surfcorder tool. Hardness testing and microstructure are performed on outer bearing and ball bearing parts. While the surface roughness testing only on the outer bearing. After all tests, it can be concluded that based on strength, hardness (wear resistance) and surface roughness on outer bearing and ball bearings, the brand that meets the optimum quality is the FMB brand because it is sufficient with the bearing working parameters that make longer life on the same aspect of use.
\end{abstract}

Keywords: bearing, strengthness, microstructure, surface roughness 


\section{PENDAHULUAN}

Di dalam konstruksi mesin, bearing merupakan bagian yang sangat penting. Bearing adalah sebagai elemen mesin yang mampu menumpu poros berbeda, sehingga putaran atau gerakan bolak-baliknya dapat berlangsung secara halus dan aman. Jika bearing tidak berfungsi dengan baik maka prestasi seluruh sistem akan menurun atau tidak dapat bekerja dengan semestinya.

Bearing merupakan komponen yang paling sering bergesekan pada saat mesin hidup akibat adanya putaran poros dan panas, maka harus memiliki persyaratan sebagai berikut [1]

1. Tahan terhadap keausan dan gesekan.

2. Tahan terhadap korosi/karat.

3. Tahan terhadap kejutan.

4. Tahan terhadap panas.

5. Kuat dan tidak mudah patah.

Dalam pemilihan produk yang menurut kebutuhan dan kualitas yang relatif handal. Kehandalan suatu produk salah satunya ditentukan oleh sifat mekanik dari bahan yang digunakan. Sifat yang penting untuk diperhatikan dari suatu bahan adalah kekuatan, kekerasan, kekakuan, ketangguhan, dan sifat lain yang dibutuhkan [2,3]. Selain itu perlu dipertimbangkan bentuk produk dan cara memproduksinya [1], dan memperhatikan sifat material ideal seperti bahan baku dan cadangannya yang mudah didapat, harga yang murah, dapat didaur ulang, hemat energi, tahan korosi, banyak penggunaannya, dan sebagainya.

Untuk mengetahui sifat-sifat suatu bahan adalah dengan melakukan suatu pengujian terhadap bahan tersebut. Pengujian yang dilakukan untuk mengetahui berbagai sifat seperti struktur, sifat teknologi (dapat ditempa, dapat diubah bentuk, dapat dilas, dan sebagainya), sifat mekanis (kekuatan tarik, kekerasan, keliatan, dan sebagainya), sifat termal, sifat dalam medan listrik, komposisi kimia, dan lain-lain. Karena pemikiran-pemikiran tersebut, penulis melakukan penelitian dalam bidang metalurgi dengan melakukan perbandingan kualitas antara empat merk bearing yang berbeda yaitu SKF, FMB, NKK, dan JAL dengan melakukan pengujian kekerasan, pengamatan struktur mikro, pengujian kekasaran, dan pengujian komposisi kimia.

\section{METODOLOGI PENELITIAN Diagram Alir Penelitian}

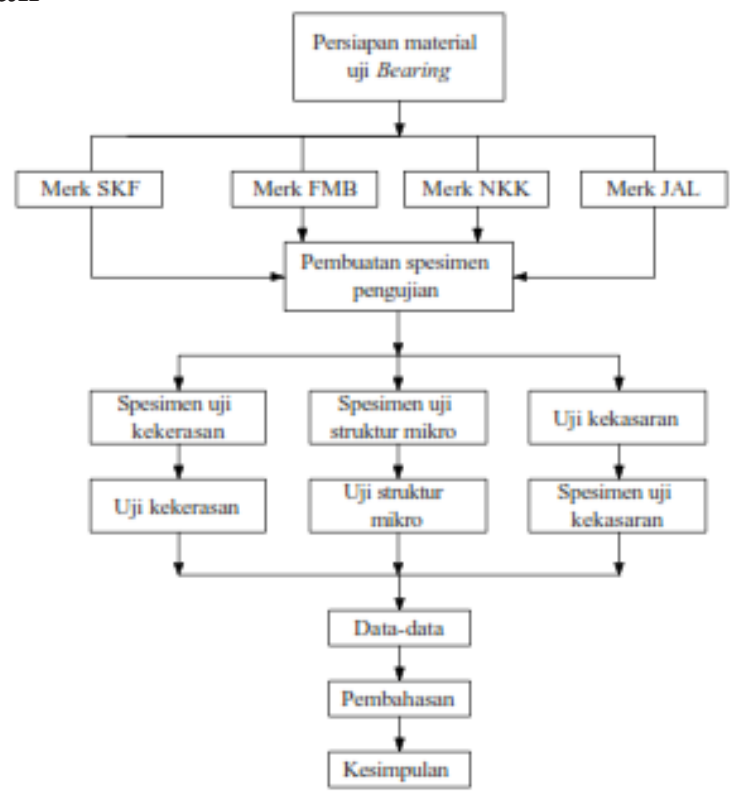

Gambar 1. Diagram alir penelitian 


\section{Material Alat Uji}

Bahan yang digunakan pada penelitian ini adalah bearing yang dibeli pada dealer resmi dengan merk SKF, FMB, NKK, dan JAL.

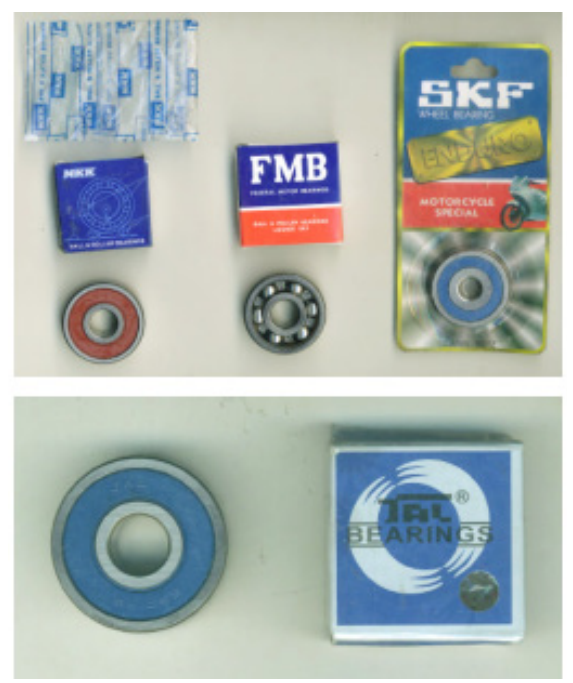

Gambar 2. Empat jenis bearing yang diteliti.

\section{Pembuatan Spesimen Uji}

1. Pemotongan

Pemotongan dilakukan dengan metode meta cut dengan pendinginan menggunakan air.

Tabel 1. Rincian benda uji yang digunakan dalam pengujian

\begin{tabular}{|c|l|c|c|}
\hline No. & Jenis pengujian & $\begin{array}{c}\text { Jumlah } \\
\text { benda uji }\end{array}$ & $\begin{array}{c}\text { Bagian } \\
\text { Yang diuji }\end{array}$ \\
\hline 1. & $\begin{array}{l}\text { Kekerasan } \\
\text { dan } \\
\text { Struktur mikro }\end{array}$ & 8 buah & $\begin{array}{c}\text { Outer } \text { dan } \text { ball } \\
\text { bearing }\end{array}$ \\
\hline 2. & Kekasaran & 4 buah & Outer bearing \\
\hline \multicolumn{2}{|c|}{ Jumlah total spesimen } & \multicolumn{2}{|c|}{ buah } \\
\hline
\end{tabular}

2. Pengikiran (grinding)

3. Pengamplasan dan peresinan

Pengamplasan dilakukan secara manual dengan menggunakan kertas amplas dan pendinginan menggunakan air. Peresinan dilakukan setelah pengamplasan dengan tujuan untuk memudahkan pemegangan spesimen karena spesimen yang terlalu kecil.

4. Pemolesan (polishing)

Dilakukan dengan tujuan untuk menghilangkan alur pemakanan akibat proses pengamplasan dengan media autosol.

5. Pengetsaan

Dilakukan khusus untuk spesimen yang akan diuji struktur mikro.

6. Pengujian kekerasan

Pengujian kekerasan yang digunakan adalah dengan menggunakan metode micro vickers.

7. Pengujian kekasaran 


\section{HASIL DAN PEMBAHASAN}

Pengujian Kekerasan

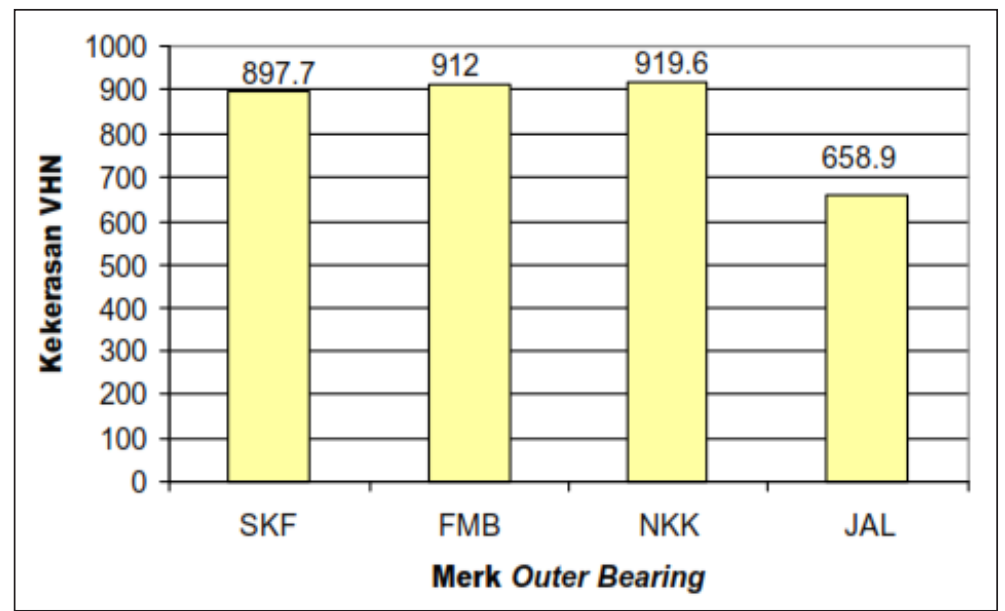

Gambar 3. Histogram harga kekerasan rata-rata pada outer bearing

Pada pengujian bagian outer bearing didapatkan harga kekerasan rata-rata tertinggi pada merk NKK sebesar 919,6 VHN disusul merk FMB sebesar 912 VHN, merk SKF sebesar 897,7 VHN dan terendah adalah merk JAL sebesar 658,9 VHN seperti ditunjukkan pada gambar 3. Dengan harga kekerasan tertinggi pada bearing merk NKK maka bagian outer tersebut akan lebih tahan lama terhadap keausan pada permukaan pasan akibat gesekan pada watu pemasangan atau perputaran poros.

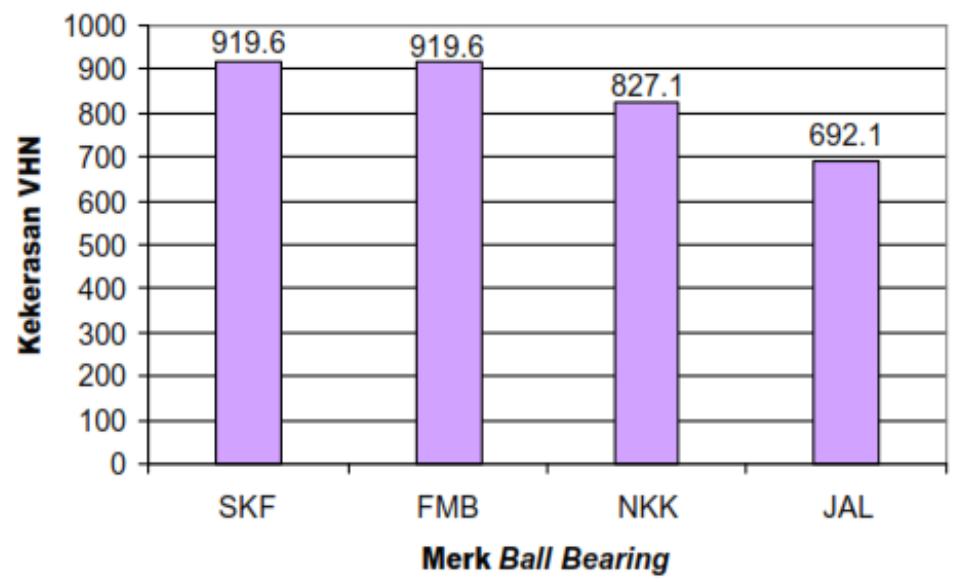

Gambar 4. Histogram harga kekerasan rata-rata pada ball bearing

Dari pengujian kekerasan pada bagian ball maka didapatkan bahwa merk SKF dan merk FMB masing-masing mempunyai harga kekerasan rata-rata yang sama yaitu sebesar 919,6 VHN yang merupakan harga kekerasan tertinggi, disusul dengan merk NKK sebesar 827,1 VHN, dan paling rendah adalah merk JAL sebesar 692,1 VHN seperti ditunjukkan pada gambar 4.

Secara umum dapat dikatakan bahwa kekerasan pada bagian bola (ball bearing) dengan cincin luar (outer bearing) lebih tinggi pada bagian bola (ball) karena secara aplikatif penerapan lapangan pada bagian bola dengan luas bidang kontak sangat kecil maka beban per satuan luas atau tekanannya menjadi sangat tinggi. Dengan demikian pada bagian bola bahan yang dipakai harus mempunyai ketahanan dan kekerasan sangat tinggi. 


\section{Pengujian Struktur Mikro}

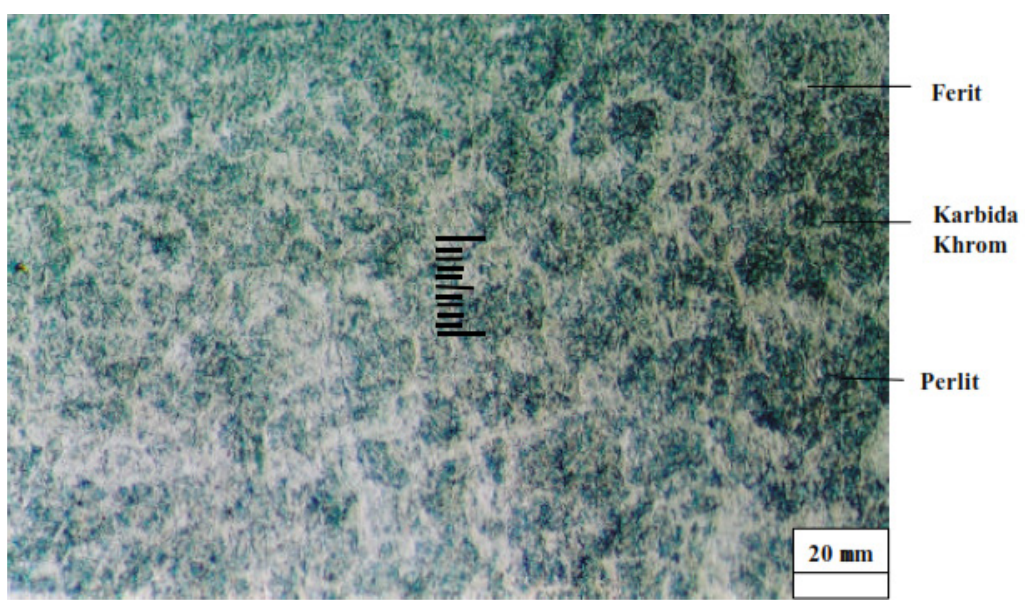

Gambar 5. Foto struktur mikro outer bearing merk SKF dengan pembesaran 500x

Sesuai yang ditunjukkan pada gambar 5, pada bagian outer bearing merk SKF menunjukkan karbida krom yang berbentuk butiran bulat kecil-kecil di dalamnya warna terang yang bersifat keras dan getas dekat dengan kristal khrom. Kristal-kristal berwarna gelam/hitam adalah perlit. Ferit yang bersifat lunak didapatkan berwarna putih di semua tempat maka keausan akan tinggi.

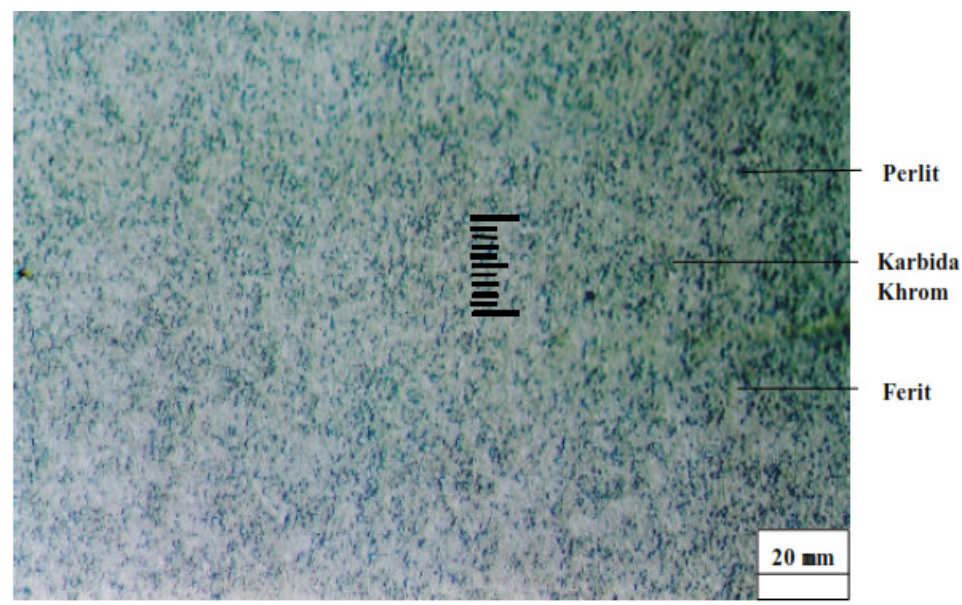

Gambar 6. Foto struktur mikro outer bearing merk FMB dengan pembesaran 500x

Gambar 6 menunjukkan hasil uji struktur mikro pada outer bearing merk FMB. Dari gambar tersebut dapat dilihat bahwa butiran bulat karbida khrom pada merk ini berukuran sangat kecil dan perlit yang berwarna gelap/hitam tampak berukuran kecil sangat halus dan lembut berbetuk bintik-bintik dengan dasar ferit yang berwarna putih. Karbida khrom merupakan ikatan antara atom karbon dengan khrom dan bersifat sangat keras. 


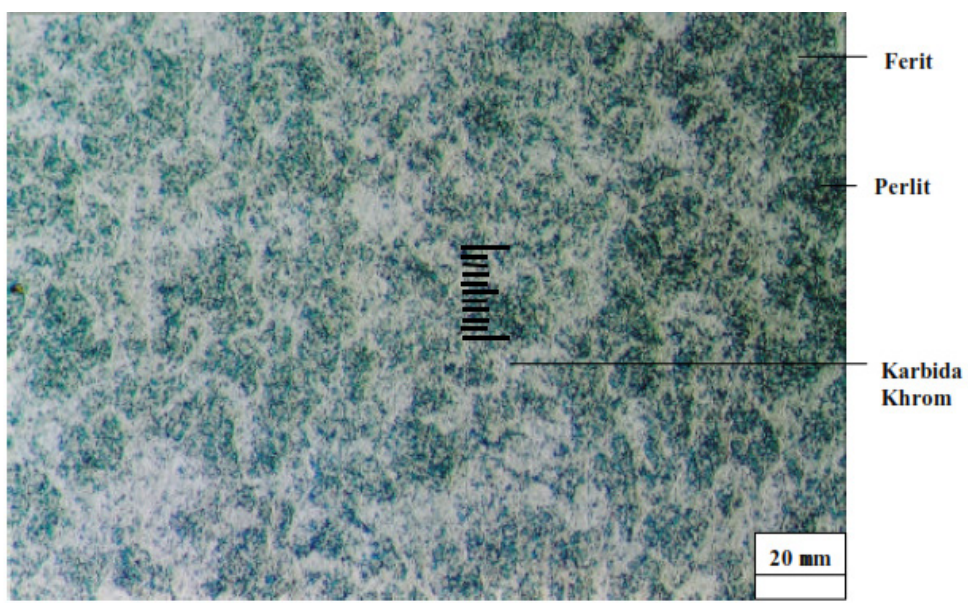

Gambar 7. Foto struktur mikro outer bearing merk NKK dengan pembesaran 500x

Dari gambar 7 di atas terlihat bahwa bagian outer bearing dari merk NKK memiliki butiran bulat kecil-kecil (karbida khrom) yang bersifat keras didapatkan merata di semua tempat dan butir perlit dengan warna gelap/hitam berukuran besar serta tebal dengan jumlah lebih banyak, sehingga berakibat merik ini memiliki harga kekerasan rata-rata tertinggi pada bagian outer daripada merk-merk lain.

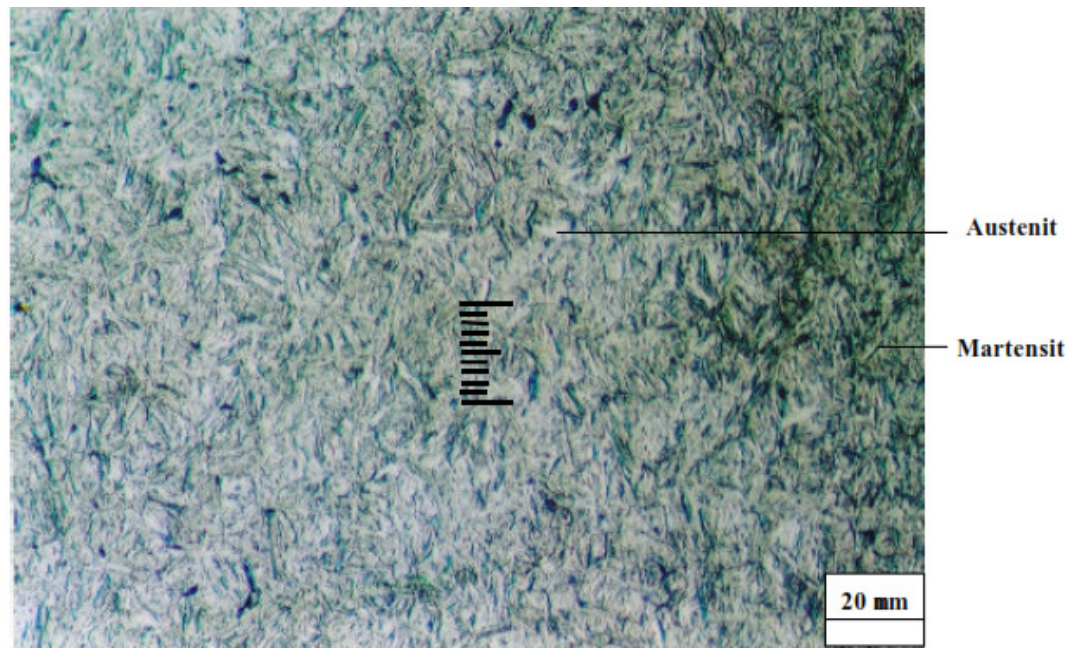

Gambar 8. Foto struktur mikro outer bearing merk JAL dengan pembesaran 500x

Sedangkan pada outer bearing merk JAL, struktur mikronya terdapat fasa martensit yang berbentuk jarum-jarum yang mempunyai kembaran dengan warna gelap/hitam seperti ditunjukkan pada gambar 8. Pada merk ini juga didapatkan sisa austenit yang tidak bertransformasi dengan warna terang sebagai latar belakang. Bentuk dan ukuran jarum-jarum martensit yang besar menunjukkan adanya pertumbuhan butir yang menimbulkan kegetasan, sehingga pada merk JAL bagian outer harga kekerasan rata-rata menduduki posisi terendah. 
ISSN: 1411-4348

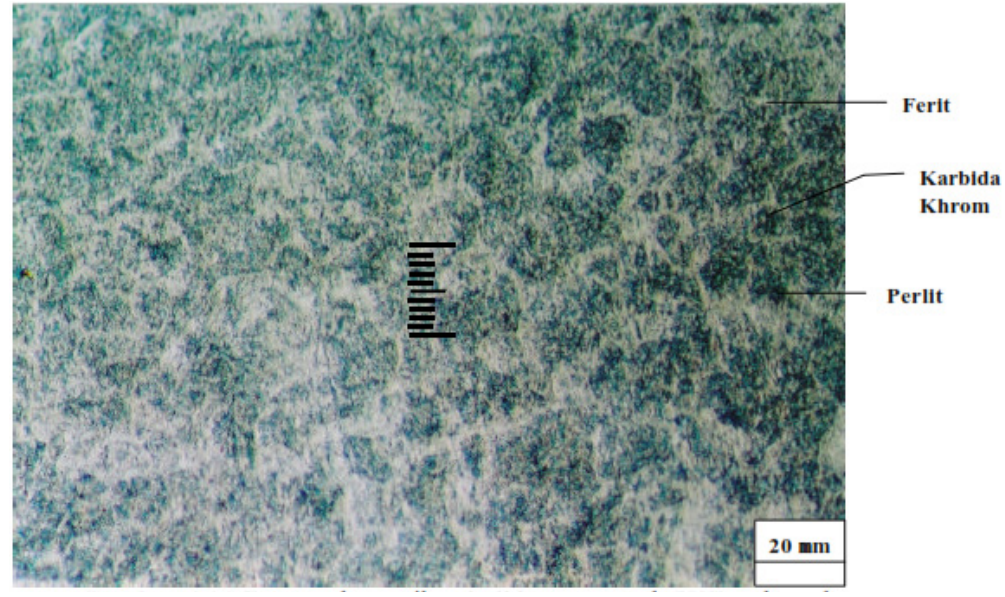

Gambar 9. Foto struktur mikro ball bearing merk SKS dengan pembesaran 500x

Pada bagian ball bearing merk SKF yang ditunjukkan pada gambar 9 menunjukkan bahwa karbida khrom (butiran bulat kecil-kecil) yang larut dalam matriks ferit berwarna putih tersebar merata. Butiran-butiran halus perlit yang berwarna gelap/hitam membentuk lapisan-lapisan yang tebal dalam jumlah banyak. Hal ini menyebabkan harga kekerasan ratarata naik pada posisi tertinggi.

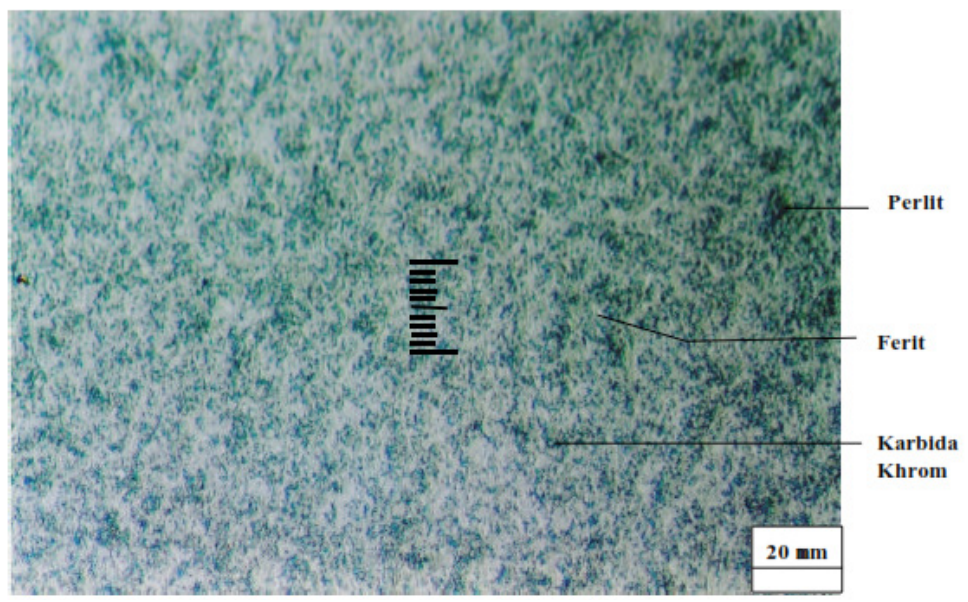

Gambar 10. Foto struktur mikro ball bearing merk FMB dengan pembesaran 500x

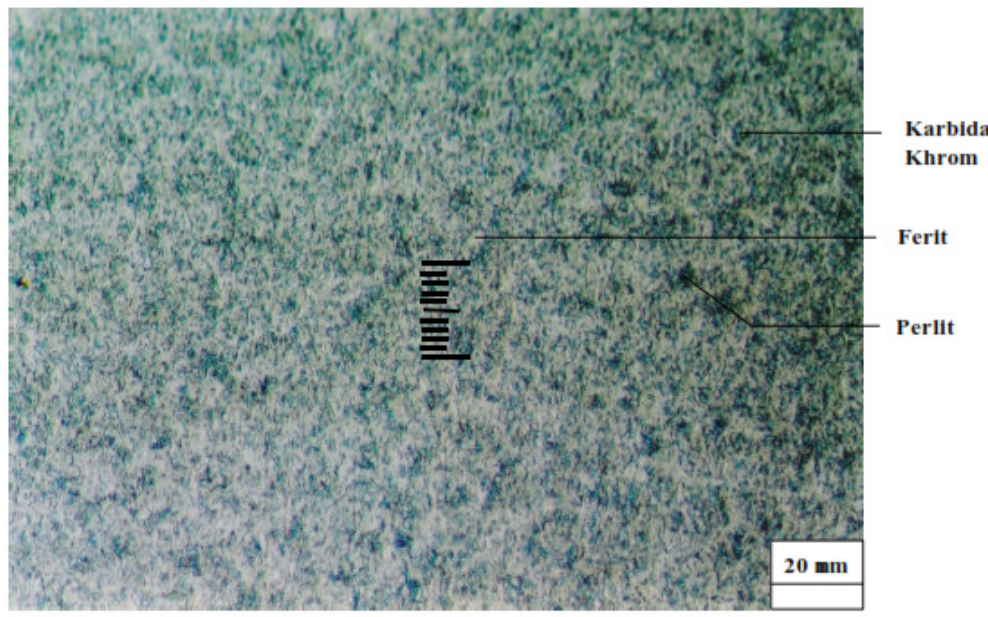

Gambar 11. Foto struktur mikro ball bearing merk NKK dengan embesaran 500x 
Gambar 10 memperlihatkan bahwa pada ball bearing merk FMB, penyusun struktur mikro tetap sama yaitu perlit dan karbida khrom, hanya kondisi yang membedakan adalah ketebalan butiran perliy dan lapisan yang agak tipis. Pada merk NKK, perlit yang berwarna gelap/hitam berkurang ketebalan dan area ferit bertambah luas sehingga kekerasannya akan berkurang (gambar 11).

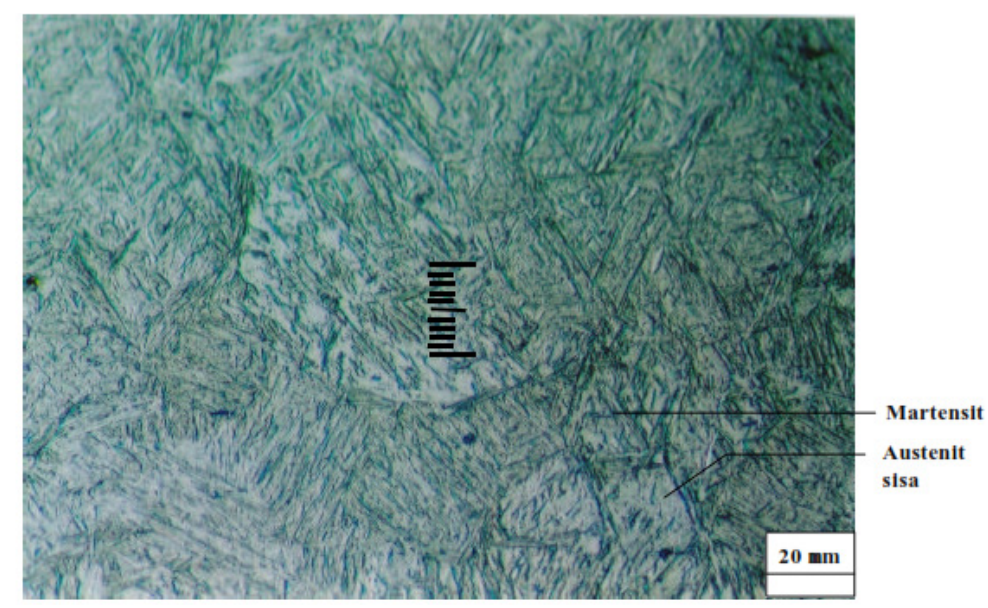

Gambar 12. Foto struktur mikro ball bearing merk JAL dengan pembesaran 500x

Untuk bagian ball bearing merk JAL, bentuk struktur menunjukkan kemungkinan pencelupan dengan minyak setelah pemanasan pada temperatur tinggi. Seperti yang terlihat pada gambar 12, pada merk ini terdapat austenit sisa berwarna putih dan martensit bilah terdiri dari kelompok-kelompok bilah yang dipisahkan oeh batas butir bersudut kecil atau besar.

\section{Pengujian Kekasaran}

Karena pada bagian cincin luar (outer bearing) baik kondisi berputar atau diam tetap mengalami gesekan dengan bagian yang ditempatinya maka perlu dievaluasi kekasaran permukaannya. Dengan demikian dapat diketahui tingkat ketelitian atas kehalusan permukaan, dimana hal ini sangat berpengaruh terhadap kondisi ketenangan dalam operasional dan umur panjang.

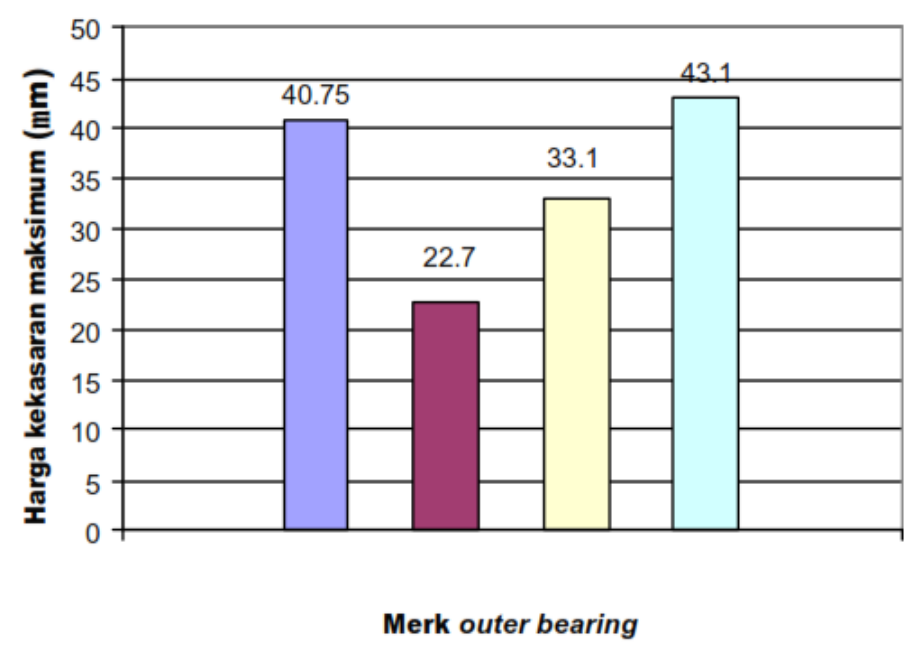

Gambar 13. Histrogram kekasaran maksimum outer bearing 
Dari pengujian kekasaran pada bagian outer bearing didapatkan data bahwa merk JAL memiliki harga kekasaran tertinggi, diikuti dengan merk SKF, NKK, dan terendah adalah FMB seperti yang ditunjukkan pada gambar 13. Pada merk JAL dengan harga kekasaran permukaan tertinggi pada bagian outer maka pada bagian permukaan terdapat bagian berongga/lembah dan puncak. Sehingga partikel-partikel halus yang terlepas akan mudah terperangkap dalam bantalan sehingga dapat menimbulkan panas dan getaran di atas normal. Kekasaran permukaan tinggi menyebabkan adanya rongga, dengan demikian terdapat beberapa bagian permukaan yang longgar maka lama kelamaan dalam pemakaian akan mudah menimbulkan slip dan terjadi getaran pada waktu bantalan berputar dengan arah beban yang tidak menentu.

Di sisi lain, merk FMB dengan harga kekasaran permukaan rendah pada bagian outer maka outer akan terpasang pada tempatnya dengan lebih kuat. Sebab jika pemasangan tersebut longgal akan memungkinkan gesekan yang terjadi antara tempat atau dudukan dengan cincin luar (outer bearing) yang terpasang tersebut sehingga mengakibatkan keausan pada permukaan pasan.

\section{KESIMPULAN}

Jika ditinjau secara umum berdasarkan kekuatan, kekerasan (ketahanan aus) serta kekasaran permukaan pada bagian outer bearing dan ball bearing maka merk yang memenuhi kualitas optimum adalah merk FMB karena sudah mencukupi dengan parameter kerja bantalan sehingga membuat umur pakai lebih panjang pada aspek penggunaan yang sama.

\section{DASAR PUSTAKA}

[1] Soelarso, Suga. K. 1991. Dasar Perencanaan dan Pemilihan Elemen Mesin. Jakarta: PT. Pradnya Paramita.

[2] Donald S. Clark. 1973. Physical Metallurgy for Engineer. New York: American Book.

[3] De Garmo E. P. 1969. Materials and Processes in Manufacturing, Mac Millan Company. New York. 